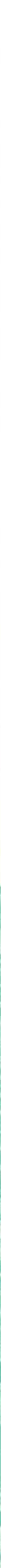





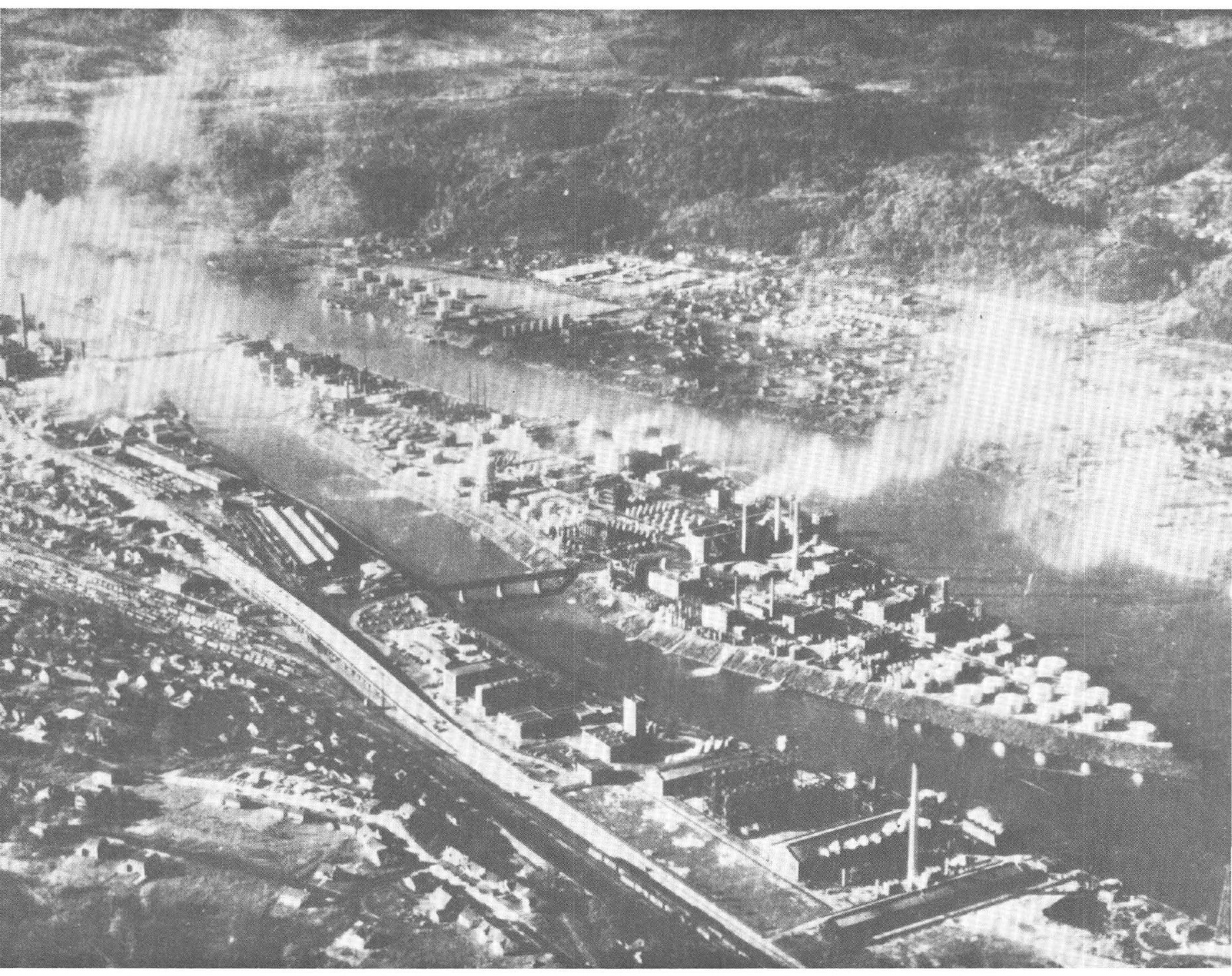

Despite the flooding hazard, flood plains have always been prime areas for industrial, commercial, and residential development. 
EXTENT AND DEVELOPMENT

OF URBAN FLOOD PLAINS 


\section{Extent and Development Of Urban Flood Plains}

By William J. Schneider and James E. Goddard

\section{WATER IN THEURBAN ENVIRONMENT}

GEOLOGICAL SURVEY CIRCULAR 601-J 
United States Department of the Interior ROGERS C. B. MORTON, Secretary

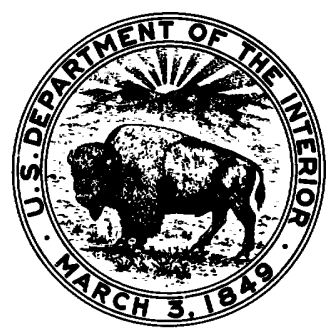

Geological Survey

V. E. McKelvey, Director 


\section{FOREWORD}

Urbanization - the concentration of people in urban areas and the consequent expansion of these areas - is a characteristic of our time. It has brought with it a host of new or aggravated problems that often make new demands on our natural resources and our physical environment. Problems involving water as a vital resource and a powerful environmental agent are among the most critical. These problems include the maintenance of both the quantity and quality of our water supply for consumption, for recreation, and general welfare and the alleviation of hazards caused by floods, drainage, erosion, and sedimentation.

A prerequisite to anticipating, recognizing, and coping intelligently with these problems is an adequate base of information. This series of reports is intended to show the relevance of water facts to water problems of urban areas and to examine the adequacy of the existing base of water information.

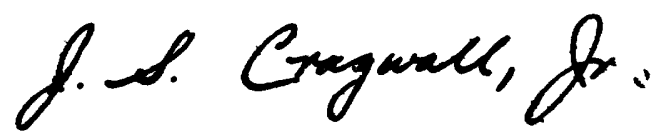

J. S. Cragwall, Jr.

Chief Hydrologist 



\section{CONTENTS}

Foreword
Abstract
Introduction
Objectives and scope
Approach
$\quad$ Defining the urban area
$\quad$ Defining the flood plain
$\quad$ Measuring the areas
$\quad$ Defining the flood-plain development
The data - J
Analyses of the data
Discussion
Reference

\section{ILLUSTRATIONS}

FrontisPiEce. Photograph showing development in the flood plain.

Figure 1. Map showing location of cities used in this study

2. Map of flood-prone area, Harrisburg, $\mathrm{Pa}$

3. Photographs showing types of uses of flood plain, Harrisburg, Pa

4. Map of flood-prone area, Spokane, Wash

5. Photographs showing types of uses of flood plain, Spokane, Wash

6. Map of flood-prone area, Phoenix, Ariz -

7. Photographs showing types of uses of flood plain, Phoenix, Ariz

8. Graph showing correlation between percent of urbanized area in flood plain and index of depth of flooding---

\section{TABLES}

TABLE 1. Area and population of selected urbanized areas

2. Areas of selected urban flood plains

3. Selected indices related to extent of flood plains in selected urbanized areas 

Water in the Urban Environment

\title{
Extent and Development of Urban Flood Plains
}

\author{
By William J. Schneider and James E. Goddard'
}

\begin{abstract}
A study of 26 urbanized areas in the United States indicates that the amount of urban area in flood plains ranges from 2.4 percent for Spokane, Wash., to 81 percent for Monroe, La. The median value is $\mathbf{1 0 . 5}$ percent, and the weighted average is $\mathbf{1 6 . 2}$ percent.

The amount of development on these flood plains also varies widely, from 11.3 percent for Lorain-Elyria, Ohio, to 97 percent for Great Falls, Mont. The median value is 57 percent, and the weighted average is $\mathbf{5 2 . 8}$ percent.

Attempts to correlate either the extent of urban area in flood plain or amount of development with three readily available indices-depth of flooding, precipitation, and physiography-showed no strong relationships. Some correlation was found between the extent of urban area in flood plain and index of depth of flooding.
\end{abstract}

\section{INTRODUCTION}

"A flood is when the water gets up to your pocketbook."

Flood plains - the natural overflow channels of rivers, streams, oceans, and other bodies of water-have always attracted man. The rich fertile soils deposited by the floodwaters have sustained an abundant agriculture. The water supplied his needs and carried away his wastes, and the rivers and oceans served as his main artery of transportation long before the railroad or the highway linked the urban centers.

The general and predictable pattern of urban growth has been one of settlement on the flood plain, followed by expansion onto higher ground to the foothills or mountains or less desirable hinterlands. The major cities of the United States, indeed of the world, have followed this pattern. Each also, to one degree or another, has paid the penalty of flooding as complacency or ignorance or sheer gambling has exposed inhabitants to floodwaters. It has been said that "Nature has a preemptive right to the flood plain," but when Nature does not exercise that right for 20 or 50 years, man too often has become complacent, careless, or a holder of short odds.

The fact is that much of our urban areas occupy flood plains. But how much? And how much have been developed? Answers to these questions are being sought to place better perspective on the problems involved in the national goal of effective flood-plain management.

Currently, no data are compiled on the extent of flood plains in our urban areas. Nor are there data on the capital investment in development of these areas. Delineation of flood plains, however, are available through many agencies, at all levels of government, including the U.S. Geological Survey. The Survey is actively engaged in programs related to flood-plain management. Yet despite the management efforts of these agencies, according to the Federal Water Resources Council, flood damages continue to increase each year. The magnitude of factors related to the problem of increasing flood damage-the amount of urban land in flood plains, the extent of development of these flood plains, and an economic evaluation of this occupancy and efforts to protect this occupancyhave never been fully assessed.

Late in 1973, the American Society of Civil Engineers, through its Urban Water Resources Research Program sponsored by the Office of Water Resources Research, U.S. Department of the Interior, completed a study of the flood-plain problem as a part of its program. Because the study was an addition to the program, it of necessity was limited, both in scope and in time. Because of relevance to their programs, several Federal agencies concerned with flooding - the U.S. Geological Survey, the U.S. Army Corps of Engineers, and the 
Tennessee Valley Authority-provided data to that study, particularly on the extent of flooding in the urban areas.

The U.S. Geological Survey, as its contribution to the American Society of Civil Engineers study, provided flood-plain information for 16 cities included in the RALI (Resource and Land Information Program) of the Department of the Interior. The effort was undertaken to demonstrate how available resources data, along with some additional data collected especially to augment the existing data, could be analyzed to meet a specific need.

\section{OBJECTIVES AND SCOPE}

The objective of this RALI study is to evaluate both the amount of flood plain in urban areas and the degree of development of these flood plains. The scope of the study is limited by the time-frame of the broader study conducted by the American Society of Civil Engineers (Goddard, 1974).

The broader study has five objectives: (1) To determine that part of urban lands in flood plains, (2) to determine that part of urban flood plains that are developed, (3) to determine the economic investment in the developed urban flood plains, (4) to determine the average annual flood damages in urban areas, and (5) to determine the economic investment in protecting urban areas from flood damage. Clearly, the efforts described here relate to objectives (1) and (2) of the broader study.

This report contains data on areal extent and degree of occupancy of flood plains in the urbanized areas of 26 cities (see fig. 1). Of these, data were supplied for 16 cities by the U.S. Geological Survey, for 1 city by the Tennessee Valley Authority, and for 9 cities by the American Society of Civil Engineers who used basic data provided by the U.S. Army Corps of Engineers. These cities represent a statistical sampling based upon variations in physiography, topography, climate, population, river size, and political entity. They were selected to represent:

Varying populations (50,000 to 7 million)

Varying types of architecture

Varying lifestyles

Total population of 20.3 million

10 percent of total U.S. population

Inland, coastal, and estuarine conditions

All major physiographic regions

28 of the 50 states

15 of the 20 major water-resources regions 28 of the 47 U.S. Geological Survey Districts
21 of the 38 U.S. Army Corps of Engineers Districts

TVA in the Tennessee Valley.

\section{APPROACH}

For each sample city the general approach for this study was to determine the areal extent of the urban area, to delineate and measure the area of the flood plains within each urban area, and to determine and measure the present extent of usage of the areas of those flood plains.

\section{DEFINING THE URBAN AREA}

The UA (urbanized area) as defined by the U.S. Bureau of Census for the 1970 census was used for this study. An urbanized area consists of a central city or cities and surrounding closely settled territory. The specific criteria for the delineation are as follows:

1. City areas.

a. A central city of 50,000 inhabitants or more in 1960 , in a special census conducted by the Census Bureau since 1960, or in the 1970 census; or

b. Twin cities, that is, cities with contiguous boundaries and constituting, for general social and economic purposes, a single community with a combined population of at least 50,000, and with the smaller of the twin cities having a population of at least 15,000 .

2. Surrounding closely settled territory, including the following (but excluding the rural portions of extended cities):

a. Incorporated places of 2,500 inhabitants or more.

b. Incorporated places with fewer than 2,500 inhabitants, provided that each has a closely settled area of 100 housing units or more.

c. Small parcels of land normally less than 1 square mile in area having a population density of 1,000 inhabitants or more per square mile. The areas of large nonresidential tracts devoted to such urban land uses as railroad yards, airports, factories, parks, golf courses, and cemeteries are excluded in computing the population density.

d. Other similar areas in unincorporated territory with lower population density provided that they serve: 


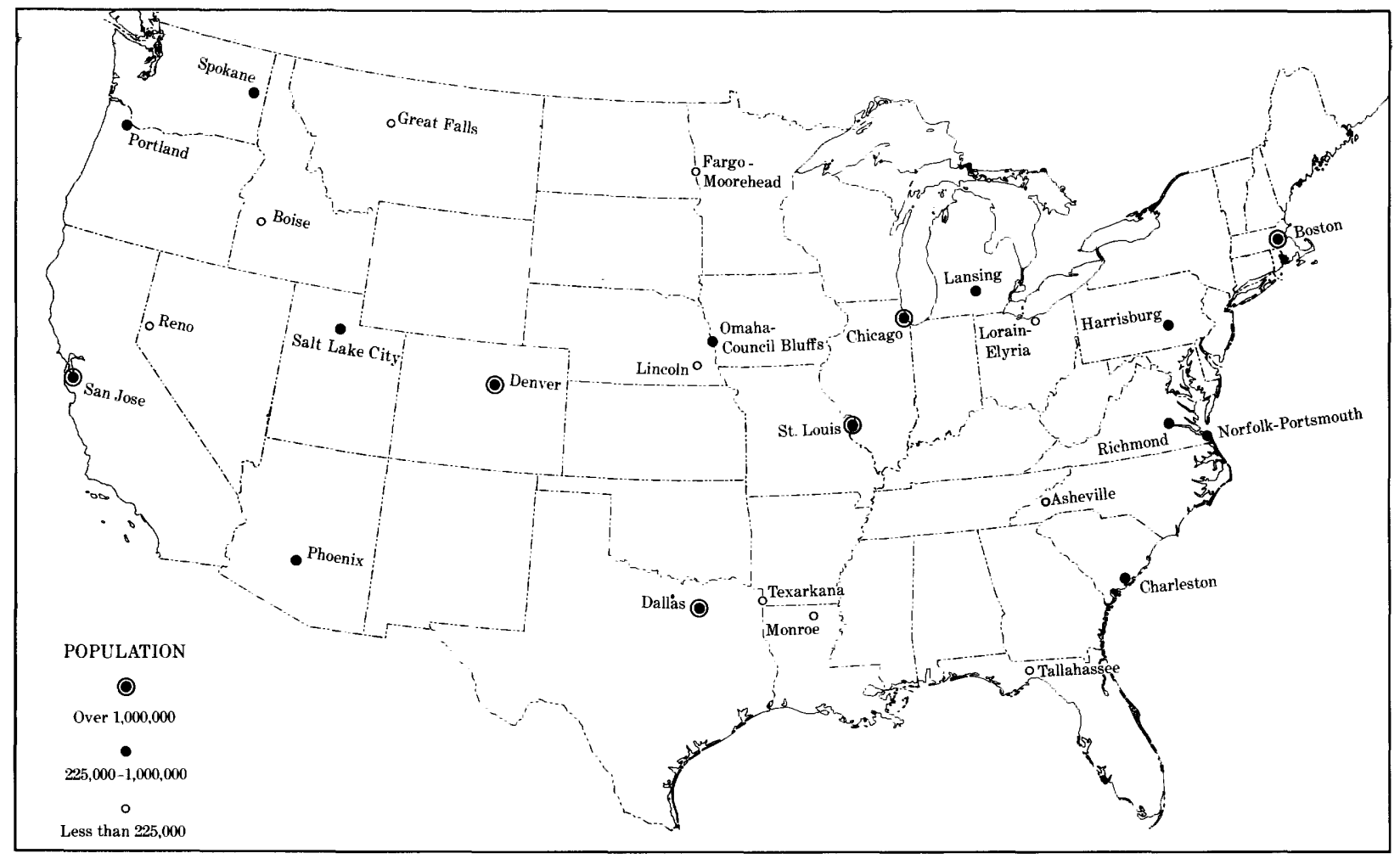

Figure 1.-Map showing location of cities used in this study. Population given is defined as that of the urbanized area.

to eliminate enclaves, or

to close indentations in the urbanized areas of 1 mile or less across the open end, or

to link outlying enumeration districts of qualifying density that are not more than $1 \frac{1}{2}$ miles from the main body of the urbanized area.

The urbanized areas based on the above criteria were chosen for several reasons. Primarily, the urbanized area is exactly what its name implies: it is urbanized. It does not include large farmland, open land, or sparsely populated expanses under private or public control that are a major part of political or other "areas" selected for statistical purposes, therefore, its use more accurately reflects the percentage of flood plain in urban areas. Furthermore, the urbanized area is a unit for which the Bureau of Census publishes demographic statistics of widely varying types, thus facilitating comparisons of the flood-plain data with other statistics. Finally, the use of the urbanized area provides homogeneity in occupancy characteristics of the selected urban areas.

\section{DEFINING THE FLOOD PLAIN}

The flood plain as defined for this study is that area which would be inundated by the natural 100-year flood (the flood level that, on an average, is exceeded once in 100 years).

It should be recognized, however, that there is great variance and freedom in the usage of the term "flood plain" that leads to frequent misunderstandings. The geologic definition of a flood plain is the relatively flat area or low lands adjoining the channel of a river, stream, or watercourse or along an ocean, lake, or other body of standing water, which has been or may be covered by floodwater. However, large parts of geologic flood plains may seldom be flooded or may be insufficiently defined to describe the flood potential. For that reason the current concept of flood-plain management generally recognizes the engineering-type definition of areas subject to specific probabilities of flooding.

Data on the 100-year flood are available from several sources. The Corps of Engineers' flood-plain information reports provide information for their SPF (standard project flood) and for 
the IRF (intermediate regional flood) which is approximately equivalent to the 100 -year flood. The TVA local flood reports provide information for flood generally equivalent to the SPF and the IRF. The U.S. Geological Survey flood-prone area maps show the areas that are subject to flooding by the 100-year flood, and their hydrologic atlas maps show areas inundated by one or more large historic floods with information to generally relate the data to 50-year or 100-year flood. The FIA (Federal Flood Insurance Administration) "Flood Information and Floodway" maps show the areas inundated by the 100-year and 500-year floods plus a basic floodway. FIA flood-insurance studies also include a rate map intended primarily for use by insurance agents to calculate rates. The rate map shows areas inundated by the 100-year and 500-year floods extended to identifiable physical features. FIA studies made prior to 1974 often contain only the rate map. The "Flood Hazard Evaluation Guidelines for Federal Executive Agencies," issued by the Federal Water Resources Council in 1972, uses the 100-year flood as one of its major criteria. Hundreds of local communities and cities and counties have adopted flood-plain regulations and some States have established programs designed around the 100-year flood or its equivalent.

Upstream regulating reservoirs, channel improvements, levees, walls, and similar structures have reduced flood hazards at many sites and changed the heights of the 100-year flood. Many of the areas that have been protected in this manner are now developed-some of them prior to the flood-control works and others after their construction.

The purpose of this study was to learn the extent of the flood plain and its relation and (or) effect on urban development; thus, to be consistent with generally accepted practices and programs of other agencies, the term "flood plain" in this study refers to the area, except the channel that will be inundated by a 100-year flood, without consideration of present or future flood-control storage, channel modifications, levees, or other works that may reduce flood levels.

Data for both natural and regulated conditions were obtained for three urban areas. These provide an indication of the relations and effect of flood plains on urban development at those sites.

\section{MEASURING THE AREAS}

Flood-prone area maps and hydrologic atlases of the U.S. Geological Survey, maps accompanying the floodplain information reports of the Corps of Engineers, and the flooded-area maps of the Tennessee Valley Authority were the principal sources of data. Maps of 1:24,000 or larger scale were used if available.

Measurements of areas were made in accordance with the following criteria:

A. Watersheds greater than $\mathbf{5}$ square miles.

1. The 100-year floods were outlined on maps.

2. The large flood-plain areas outlined on maps were planimetered using standard techniques.

3. Some small, narrow, elongated floodplain areas were divided into reaches. The length of each reach was measured, and the average width of each respective reach was estimated or measured. These areas constitute a small part of the total flood plain for any urbanized area.

4. Water-surface areas of streams, lakes, and reservoirs, large enough to be shown with double lines or in blue on standard topographic quadrangles were excluded.

5. Islands in large water areas were included as flood plain where so designated on the maps. Those of about 20 acres or larger were measured. A visual estimate of the total area of many smaller islands was made.

B. Watersheds less than 5 square miles.

1. Streams for which the 100-year flood plains were not outlined on maps (less than 5 square miles) were divided into reaches. The length of each reach was measured, and an estimate of the average width of flood plain for each respective reach made. Such cursory estimates were based on available topographic maps, size of watershed, personal knowledge of terrain and hydrologic conditions, and judgment. This procedure was applied to all streams or watercourses that are more than 3 miles in length or have a drainage area 
exceeding 2 square miles. Measurements extended upstream to a point where the drainage area was approximately 2 square miles. These totals were generally less than 2 percent of the total flood-plain area.

C. Total urbanized areas.

1. Total area of each urbanized area, except Asheville and Texarkana, was taken from Bureau of Census records. Areas for Texarkana and Asheville were measured by planimeter.

\section{DEFINING THE FLOOD PLAIN DEVELOPMENT}

The flood plains were classified as "undeveloped" or "developed," and the developed part was measured.

"Developed" flood plains were defined as those flood plains where:

1. More than one-third of the acreage, whether continuous or interspersed, is actively used for residential, commercial, or industrial purposes; or

2. Plans exist for development to a degree outlined in (1) and there is assurance that the development will be accomplished soon; or

3. State or local planning and (or) development agencies have classified the land as being developed; or

4. The Corps of Engineers has classified them as being "built-up" and measured for its Civil Works Information System records.

Several types of flood plains and their uses are illustrated in figures 2-7.

\section{THE DATA}

The data measured and compiled for this study are given in tables 1 and 2 .

Table 1 gives the area and population of the selected urbanized areas. Data are from the U.S. Bureau of Census for 1970 except for Asheville and Texarkana. For Asheville, the Bureau limits were used but new measurements were made of the area. Readily available flood-plain data from the Corps of Engineers for Texarkana included recent expansions of the corporate boundaries.

Table 2 gives the urban flood-plain areas and parts thereof which had been developed. The areas shown are for the 100-year flood under natural or unregulated conditions.
In some areas, local flood-protection works and upstream regulation provide some degree of flood protection, often considerably reducing the areas susceptible to flooding. Measurements were made for both natural and regulated conditions at three urbanized areas. At Omaha-Council Bluffs, for example, structural flood-control measures have reduced the area susceptible to flooding by the 100-year flood from 50.6 square miles to 23.2 square miles with only 8.3 square miles developed. At Monroe, flood-control measures have reduced the flood-plain area from 32.5 to 3.5 square miles with only 0.9 square miles developed; and at St. Louis, from 136.1 to 45.9 square miles with only 7.4 square miles developed.

\section{ANALYSES OF THE DATA}

There is an extremely wide variation in the extent of flood plains in urbanized areas. For the 26 urbanized areas selected for this study, the percent of area in flood plain ranges from 2.4 percent for Spokane, Wash. to 81.0 percent for Monroe, La. It should be noted, however, that the extent of flood plain in Monroe is exceptional for the areas sampled. The next largest value is less than half of that for Monroe-40.1 percent for Charleston, S.C. The median value is 10.5 percent, and the weighted average is 16.2 percent.

The development of the flood plains in the urbanized areas also varies widely. The least developed of the flood plains of the urbanized areas used in this study is in Lorain-Elyria, Ohio-11.3 percent of the total flood-plain area-and the most highly developed is that of Great Falls, Mont. -97.0 percent developed. The median value is $\mathbf{5 7 . 0}$ percent, and the weighted average is $\mathbf{5 2 . 8}$ percent.

Because of the reconnaissance nature of this study and the original objective of defining solely the extent and occupancy of flood plains in urbanized areas, no attempt was made at collecting detailed supplemental data for analyses. However, readily available data on a few indices related to flooding were developed to provide some preliminary analyses of the data. These attempts are intended more to provoke further study than to provide definitive answers.

Table 3 gives indices of three aspects of flooding (depth of flooding, precipitation, and physiography) for which data were readily available. 


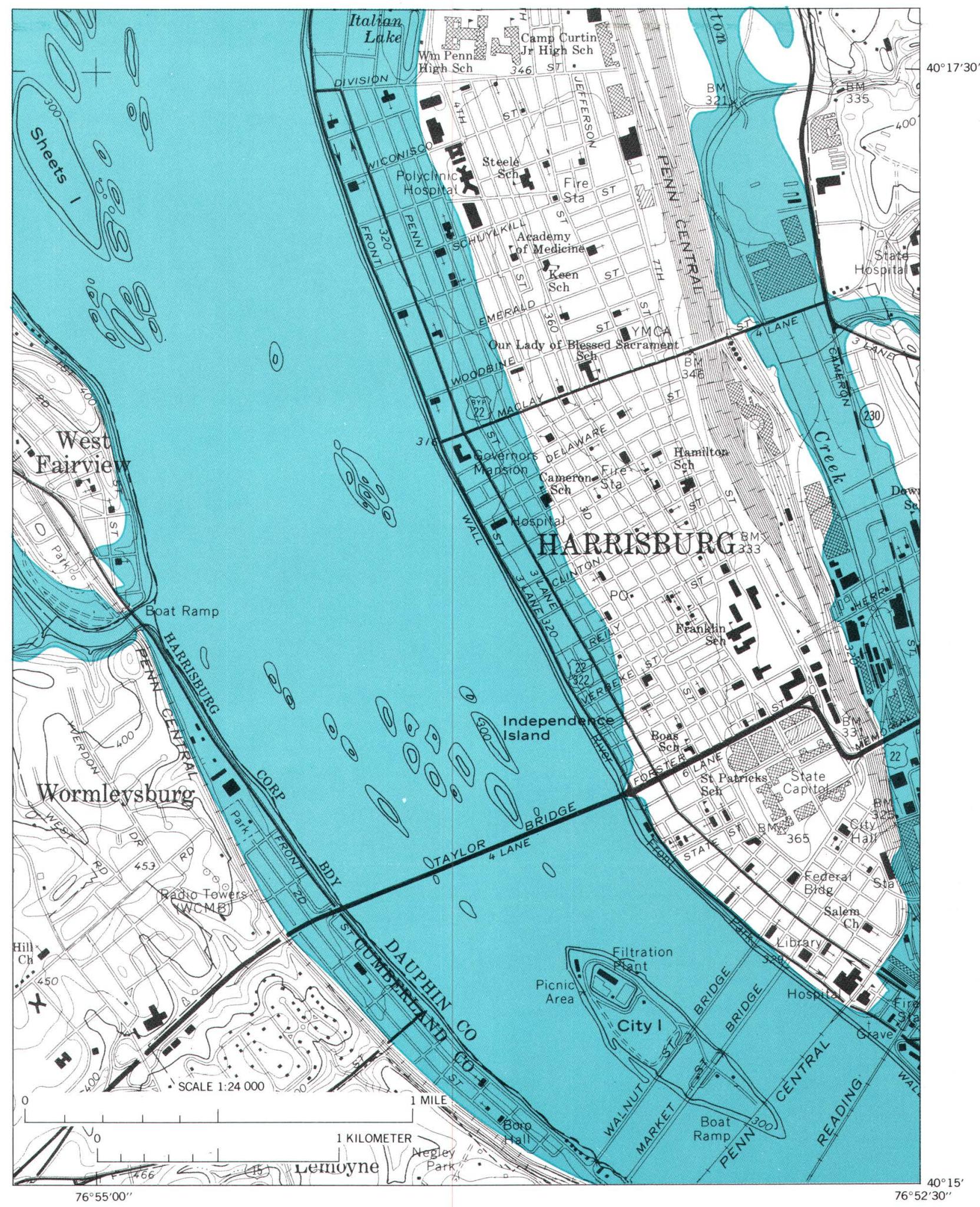

Figure 2.-Flood-prone area, Harrisburg, Pa. 

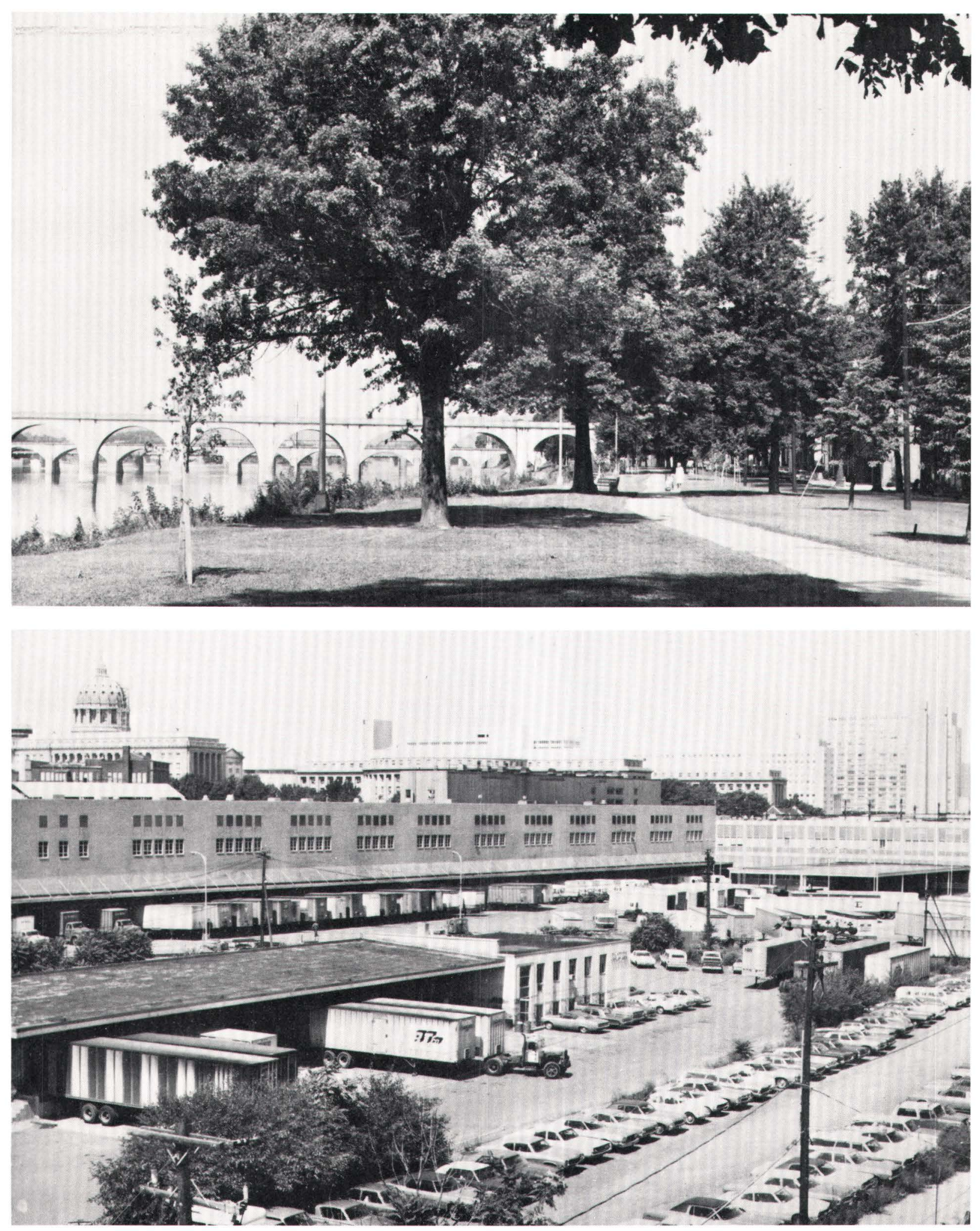

Figure 3.-Types of uses of flood plain, Harrisburg, Pa. 


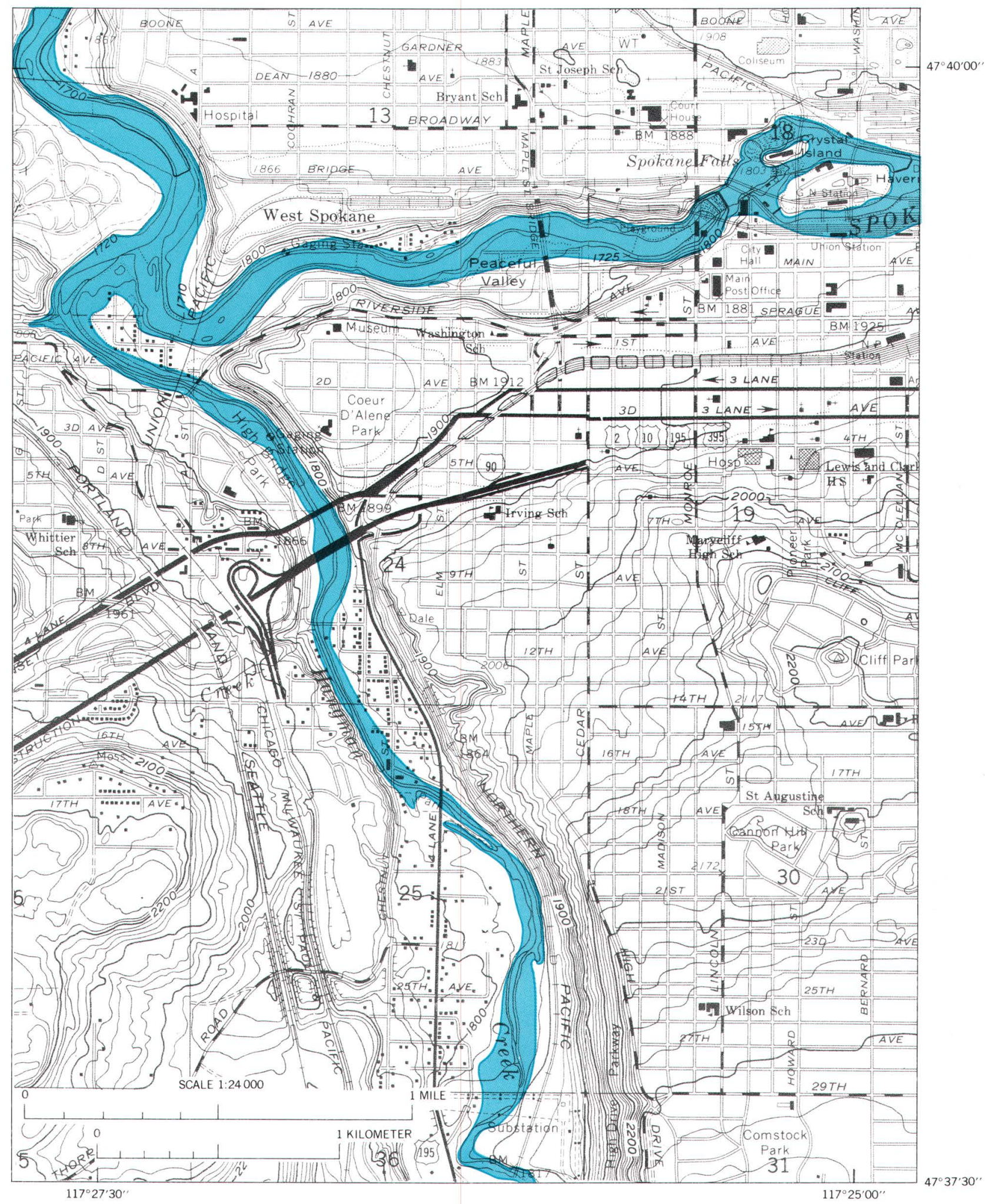

Figure 4.-Flood-prone area, Spokane, Wash. 


\section{A}
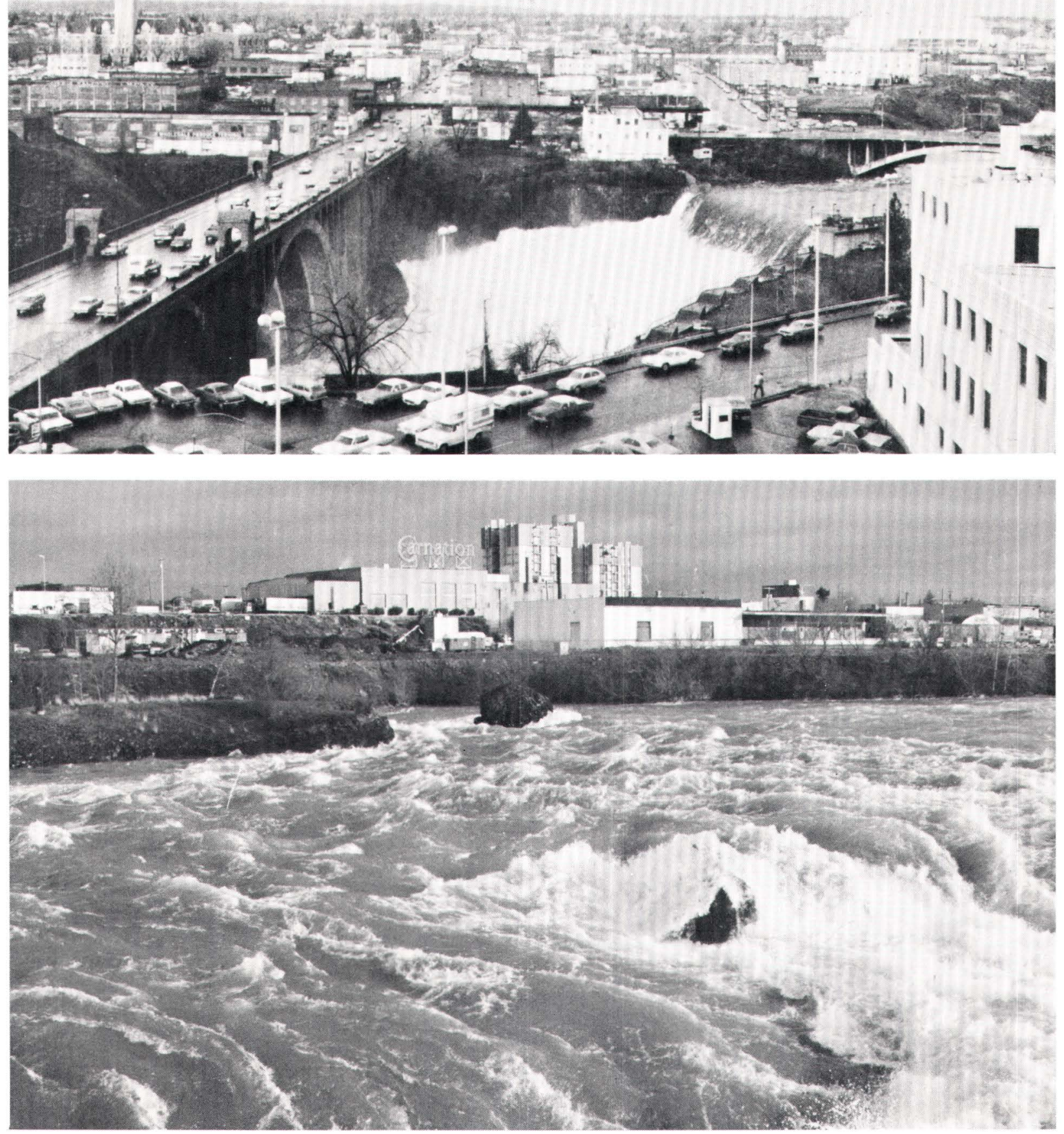

Figure 5.-Types of uses of flood plain, Spokane, Wash. 


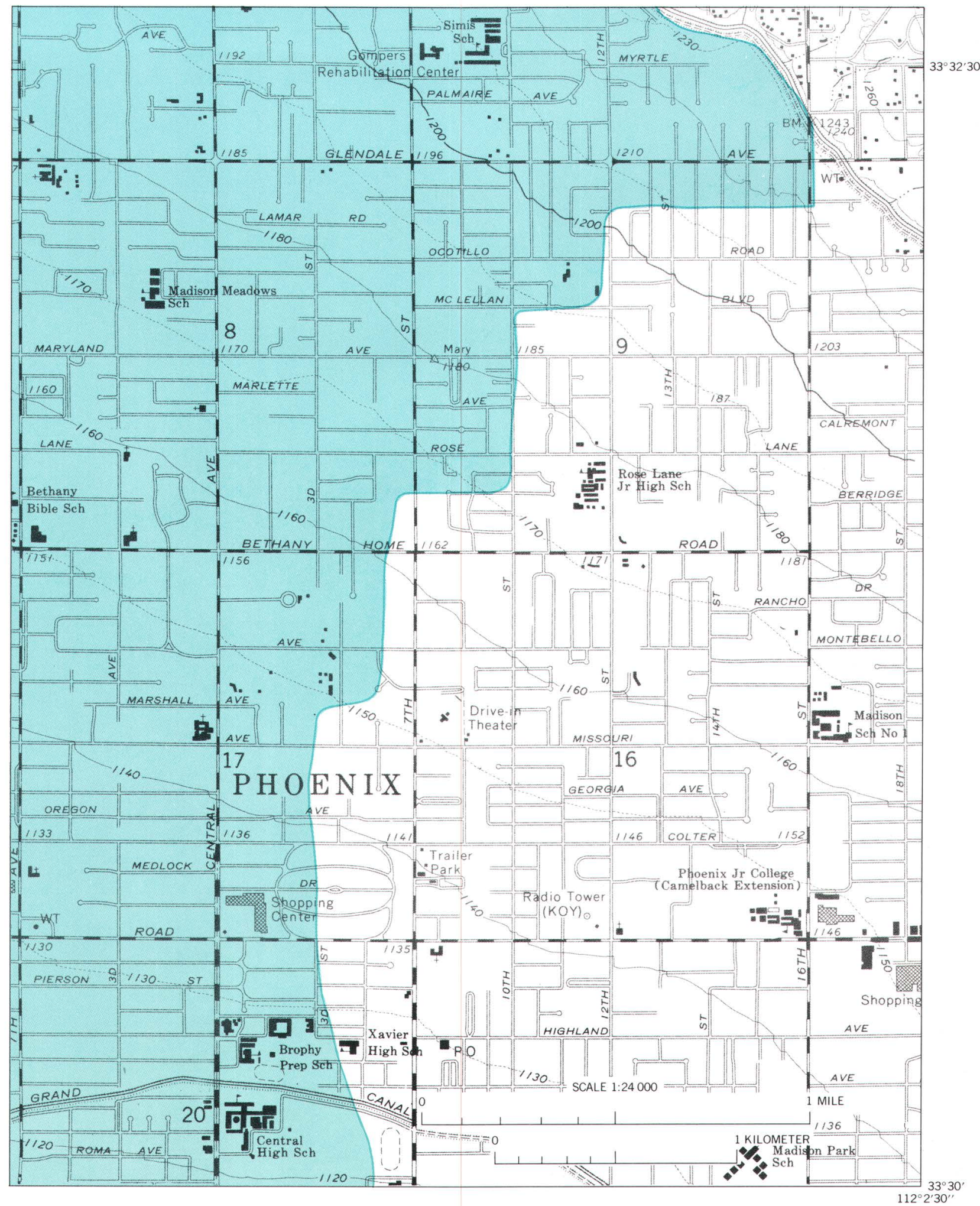

Figure 6.-Flood-prone area, Phoenix, Ariz. 

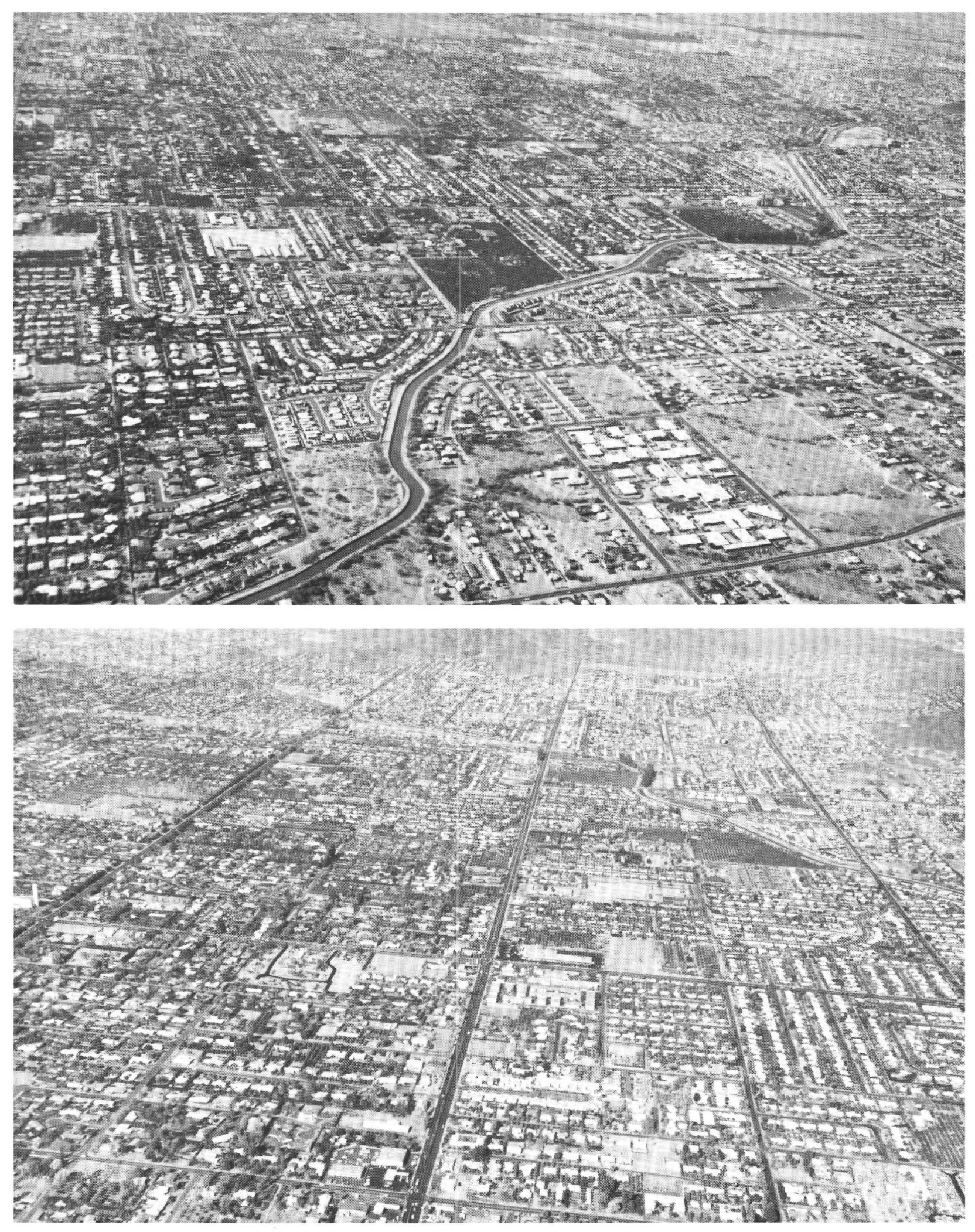

Figure 7.-Types of uses of flood plain, Phoenix, Ariz. 
TABLE 1.-Area and population of selected urbanized areas

\begin{tabular}{|c|c|c|c|}
\hline Urbanized areas & $\begin{array}{l}\text { Population } \\
\text { (1000's) }\end{array}$ & $\underset{\text { (sq.mi.) }}{\text { Land area }}$ & $\begin{array}{c}\text { Population } \\
\text { density } \\
(1,000 / \text { sq.mi. })\end{array}$ \\
\hline Asheville, NC _-- & 72.5 & 38.2 & 1.90 \\
\hline - & 85.2 & 29.4 & 2.90 \\
\hline 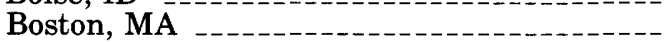 & $2,652.6$ & 664.4 & 3.90 \\
\hline 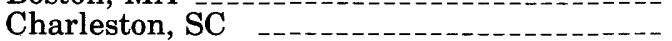 & 228.4 & 99.2 & 2.30 \\
\hline - & $6,714.6$ & $1,277.2$ & 5.26 \\
\hline 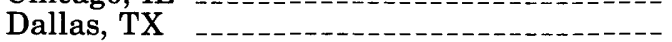 & $1,338.7$ & 674.2 & 1.99 \\
\hline Denver, CO & $1,047.3$ & 292.8 & 3.58 \\
\hline Fargo-Moorhead, ND-MN & 85.5 & 23.5 & 3.64 \\
\hline Great Falls, MT & 70.9 & 21.8 & 3.25 \\
\hline Harrisburg, PA & 240.8 & 78.4 & 3.10 \\
\hline Lansing, MI & 229.5 & 73.4 & 3.13 \\
\hline Lincoln, NB & 153.4 & 52.1 & 2.95 \\
\hline Lorain-Elyria, $\mathrm{OH}$ & 192.3 & 106.4 & 1.81 \\
\hline Monroe, LA & 90.6 & 40.1 & 2.26 \\
\hline Norfolk-Portsmouth, VA & 668.3 & 299.0 & 2.24 \\
\hline Omaha-Council Bluffs, NB-IA & 491.8 & 151.2 & 3.25 \\
\hline Phoenix, AZ & 863.4 & 387.5 & 2.21 \\
\hline - & 824.9 & 266.8 & 3.10 \\
\hline Reno, NV & 99.7 & 37.5 & 2.66 \\
\hline Richmond, VA & 416.6 & 144.6 & 2.98 \\
\hline St. Louis, MO-IL & $1,882.0$ & 460.6 & 4.19 \\
\hline Salt Lake City, UT & 479.4 & 184.3 & 2.60 \\
\hline San Jose, CA & $1,025.3$ & 277.2 & 3.70 \\
\hline Spokane, WA & 229.6 & 77.8 & 2.95 \\
\hline Tallahassee, FL & 77.9 & 29.8 & 2.61 \\
\hline Texarkana, TX-AR & 58.6 & 30.8 & 1.90 \\
\hline Total & $20,359.4$ & $5,831.7$ & \\
\hline
\end{tabular}

TABLE 2.-Areas of selected urban flood plains

\begin{tabular}{|c|c|c|c|c|}
\hline \multirow[t]{2}{*}{ Urbanized area } & \multicolumn{2}{|c|}{ Flood plain } & \multicolumn{2}{|c|}{ Developed } \\
\hline & $\begin{array}{c}\text { Area } \\
\text { (sq.mi.) }\end{array}$ & $\begin{array}{l}\text { Percent of } \\
\text { urbanized } \\
\text { area }\end{array}$ & $\underset{\text { (sq.mi.) }}{\text { Area }}$ & $\begin{array}{l}\text { Percent of } \\
\text { flood plain } \\
\text { total }\end{array}$ \\
\hline Asheville, NC & 1.6 & 4.4 & 1.0 & 65.0 \\
\hline Boise, ID & 2.5 & 8.5 & 2.1 & 84.0 \\
\hline Boston, MA & 62.4 & 9.4 & $11: 9$ & 19.1 \\
\hline Charleston, SC & 39.8 & 40.1 & 21.2 & 53.3 \\
\hline Chicago, IL & 131.8 & 10.3 & 75.1 & 57.0 \\
\hline - & 146.1 & 21.7 & 28.0 & 19.2 \\
\hline Denver, $\mathrm{CO}$ & 30.6 & 10.5 & 19.1 & 62.2 \\
\hline Fargo-Moorhead, ND-MN & 9.4 & 40.0 & 5.1 & 54.3 \\
\hline Great Falls, MT & 2.0 & 9.2 & 1.9 & 97.0 \\
\hline Harrisburg, PA & 9.7 & 12.4 & 8.1 & 83.5 \\
\hline Lansing, MI & 4.8 & 6.5 & .9 & 18.8 \\
\hline Lincoln, NB & 13.8 & 26.5 & 6.9 & 49.6 \\
\hline Lorain-Elyria, OH & 5.3 & 5.0 & .6 & 11.3 \\
\hline Monroe, LA & 32.5 & 81.0 & 26.8 & 82.4 \\
\hline Norfolk-Portsmouth, VA & 59.2 & 19.8 & 15.5 & 26.2 \\
\hline Omaha-Council Bluffs, NB-IA & 50.6 & 33.5 & 23.1 & 45.5 \\
\hline Phoenix, AZ & 71.2 & 18.4 & 63.5 & 89.2 \\
\hline Portland, OR & 14.5 & 5.4 & 8.5 & 58.7 \\
\hline Reno, NV & 2.0 & 5.3 & .9 & 45.0 \\
\hline Richmond, VA & 12.9 & 8.9 & 1.7 & 13.2 \\
\hline St. Louis, MO-IL & 136.1 & 29.6 & 91.7 & 67.4 \\
\hline Salt Lake City, UT & 12.9 & 7.0 & 10.1 & 78.3 \\
\hline San Jose, CA & 80.0 & 28.8 & 67.9 & 84.7 \\
\hline Spokane, WA & 1.9 & 2.4 & .9 & 47.4 \\
\hline Tallahassee, FL & 3.1 & 10.4 & 2.6 & 83.9 \\
\hline Texarkana, TX-AR & 4.7 & 13.8 & 2.1 & 44.2 \\
\hline Total & 941.4 & & 497.2 & \\
\hline Weighted average & & 16.2 & & 52.8 \\
\hline
\end{tabular}




\begin{tabular}{|c|c|c|c|}
\hline Urbanized area & $\begin{array}{l}\text { Index of } \\
\text { flooding }\end{array}$ & $\begin{array}{l}\text { Index of } \\
\text { precipitation }\end{array}$ & $\begin{array}{l}\text { Index of } \\
\text { elevatior }\end{array}$ \\
\hline Asheville, NC & 24 & 38 & 2,242 \\
\hline Boise, ID & 10 & 11 & $\mathbf{2}, 838$ \\
\hline Boston, MA & 5 & 43 & 15 \\
\hline Charleston, SC & 14 & 37 & 9 \\
\hline Chicago, IL__-_._- & 19 & 33 & 658 \\
\hline Dallas, TX & 31 & 35 & 481 \\
\hline Denver, $\mathrm{CO}$ & 12 & 15 & 5,332 \\
\hline Fargo-Moorhead, ND-MN & 25 & 18 & 896 \\
\hline Great Falls, MT & 11 & 14 & 3,664 \\
\hline Harrisburg, PA & 26 & 38 & 338 \\
\hline Lansing, MI & 16 & 31 & 841 \\
\hline Lincoln, NB & 25 & 27 & 1,150 \\
\hline Lorain-Elyria, $\mathrm{OH}$ & 21 & 35 & 777 \\
\hline Monroe, LA & 38 & 51 & 78 \\
\hline Norfolk-Portsmouth, VA & 8 & 45 & 22 \\
\hline Omaha-Council Bluffs, NB-IA & 31 & 28 & 1,323 \\
\hline Phoenix, AZ & 20 & 7.2 & 1,117 \\
\hline Portland, OR & 30 & 37 & 21 \\
\hline Reno, NV & 15 & 7 & 4,404 \\
\hline Richmond, VA & 28 & 44 & 164 \\
\hline St. Louis, MO-IL & 50 & 36 & 555 \\
\hline Salt Lake City, UT & 10 & 14 & 4,220 \\
\hline San Jose, CA & 17 & 14 & 95 \\
\hline Spokane, WA & 13 & 17 & 2,349 \\
\hline Tallahassee, FL & 10 & 57 & 55 \\
\hline Texarkana, TX-AR & 18 & 48 & 390 \\
\hline
\end{tabular}

They have been listed to facilitate some crude analyses. The indices were derived as follows. The index of flooding, to represent possible depth of inundation as a measure of extent of flooding, was computed as the difference (in feet) in elevation of low water and the 100-year flood elevation for the major stream in an urbanized area. Data used for computation were records of the U.S. Geological Survey streamflow-measuring station on the major stream located in or nearest to the major downtown area. For regulated streams, the index was computed on the basis of the elevation of the unregulated 100-year flood. The index of precipitation is the average annual precipitation in inches at the principal first-order weather station in the area. The index of elevation is the elevation in feet of the U.S. Weather Service precipitation gage used as the index of precipitation.

The data in tables 1,2 , and 3 were analyzed by a step-forward regression analysis using both the percent of flood plain and the percent of development as dependent variables in correlation with the total land area, the population density, and the indices of flooding, precipitation, and elevation.
There is no significant correlation between the size of the urbanized area and the percent of the land in flood plain. Nor is there any significant correlation between the population density of the urbanized area and the percent of occupancy of those flood plains. Of the variables considered in this study, only one relationship seems to be appreciable: the percent of urbanized flood-plain related to the index of flooding. That relationship could be considered:

$$
\mathrm{PFP}=1.85+0.80 \mathrm{FI}
$$

where PFP is the percent of urbanized area in flood plain, and FI is the index of flooding. However, the low coefficient of correlation 0.49 explains only 24 percent of the variance. It is based on two extreme values-those for Monroe and St. Louis-and without those values the relationship would not be significant. The relationship is shown graphically in figure 8.

This minimal consideration of a few factors or indices indicates there probably is no one factor that explains the inclusion of flood plains in urban areas or the degree of development of those flood plains. However, further studies may develop im- 


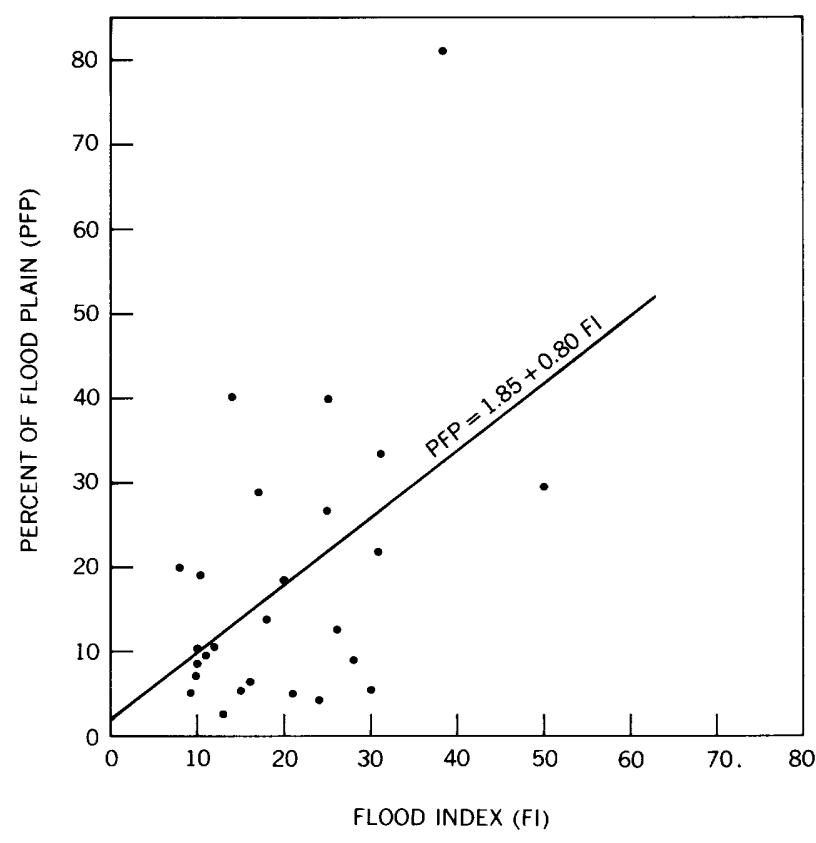

FIgURE 8.-Correlation between percent of urbanized area in flood plain and index of depth of flooding.

portant relationships for other combinations of factors.

\section{DISCUSSION}

The analyses presented in this report must be evaluated in terms of a dichotomic situation. The measurements of the flood plains and their occupancy are precise in terms of the definitions accepted for this study. The flood plains are those of the 100-year flood; the urbanized areas are those defined by the U.S. Bureau of the Census; the occupancy of the flood plains is defined by reasonably precise criteria. These measurements were the primary purpose of this study: to determine through a statistical sampling of the urbanized areas the extent and occupancy of their flood plains. The range of data indicates no consistency in amounts.

At least part of the inconsistency is related to the arbitrary boundaries of the urbanized areas. In many cities, flood-plain areas have been excluded from the urbanized areas because of the particular land-use pattern of the area. Two examples are worth citing.

At St. Louis, considerable flood-plain area lies outside the boundary of the urbanized area but is abutted on one or both sides by the urbanized area. Determining the area of such flood plains is not easy because of the difficulty in associating the plains areas with the urbanized area, but an estimate of 5 square miles of developed flood plain and 60 square miles of undeveloped flood plain is reasonable. Inclusion of this area brings the total flood-plain area to 38 percent instead of 30 percent.

At Portland, major parts of the Columbia River flood plain are not included in the urbanized area. Areas outside the urbanized area include the Portland Air Force Base, the Portland International Airport, and other commercial developments. Although these areas were not determined accurately because of the difficulty in defining limits, as much as 30 square miles of flood plain could be considered in this category. This would triple the proportion of flood plain, increasing the flood plain from 5.4 to 16.7 percent.

It should again be pointed out that the flood plains designated for this study are those for the natural 100-year flood. Flood-protection measures in many areas have reduced the areas susceptible to flooding.

Only limited attempts were made to relate the extent and occupancy of the measured flood plains to associated factors. Again, it must be emphasized that the original scope of the effort-to delineate the flood plains-precluded any major research effort in describing causative factors. The reconnaissance relationships explored here are not intended as definitive attempts, but rather as stimuli to further detailed efforts to understand the natural physiographic setting and the economic and social stimuli that control occupancy of flood plains.

\section{REFERENCE}

Goddard, J. E., 1974, An evaluation of urban flood plains: Am. Soc. Civil Engineers, Tech. Memo. 19, 40 p. (Also available from the Natl. Tech. Inf. Service, U.S. Dept. Commerce, Springfield, Va. 22151, NTIS PB-227337.)

"U.S. GOVERNMENT PRINTING OFFICE: $1974-543-585 / 138$ 